\title{
Representation of Keris in The Jateng Gayeng Brand Identity: From Weapon to Icon
}

\author{
Prakas Agrestian', Deny Tri Ardianto $^{2}$, Theresia Widyastuti ${ }^{3}$ \\ \{agrestian.p@student.uns.ac.id ${ }^{1}$, denytri@staff.uns.ac.id², \\ theresia_widiastuti@staff.uns.ac.id $\left.{ }^{3}\right\}$ \\ ${ }^{1,2,3}$ Universitas Sebelas Maret, Surakarta, Indonesia
}

\begin{abstract}
Brand identity is not only used by companies or commercial products. Various countries and cities throughout the world also use the brand identity as a cultural existence. It began to be used as an image of the region in order to lift the presence of local culture in Indonesia. Central Java as a part of Indonesia's province also uses brand identity in the face of international competition. Keris is used as an icon on the brand identity that is carried, because it is one of Javanese local cultures that has been recognized by the world. It has various forms and histories can be found in various meanings that contain noble values. In this study, we will discuss about the keris which is used as an icon in the brand identity owned by Central Java called Jateng Gayeng. The meaning of the keris symbol can be investigated why it is used as the main icon in the Jateng Gayeng brand identity. The purpose of this study was to find out the meaning of representation of keris which was described through the logo in the brand identity of Jateng Gayeng. Central Java as one of the provinces with a wealth of potential that is so complex to interpret the keris not only as an art object but as a cultural power and personality image of its people as revealed by its predecessors.
\end{abstract}

Keywords: keris, jateng gayeng, brand identity

\section{INTRODUCTION}

Central Java as a province with such complex cultural characteristics has a variety of potential that can be developed as a regional identity. The province with the third highest population density in Indonesia inaugurated the brand identity with the name Jateng Gayeng in 2015. Brand identity is the process of creating images that are formed from people's perceptions [1]. Central Java communities have different perceptual characteristics from other regions, this encourages the creation of Jateng Gayeng. Brand identity processes dynamically and develops from time to time through influential input between brand owners and other social elements [2]. Jateng Gayeng also processes as brand identity develops and influences its status with its people and communities outside Central Java. When the brand identity is communicated and interpreted, it will create an equal or growing sign in the minds of the community and stakeholders [3]. Jateng Gayeng is continuously promoted as a brand identity of Central Java in the hope of creating a good image in the minds of the general public. According to the governor's 
regulation, the t-shirt with the picture "Jateng Gayeng" must be worn by workers in every event held by government institutions throughout the Central Java region [4]. This is one step in how Central Java Province promotes Jateng Gayeng as a strong brand identity symbolized by a keris.

Keris is one of Indonesia's traditional weapons [5], as a representation on the brand identity of Jateng Gayeng, which is part of the lives of Indonesians, especially Javanese, and has become one of Indonesia's cultural heritage [6]. This has been happening gradually until now. Keris is a visual object and becomes a local icon of the nation's creative products that have become a global icon. Jateng Gayeng also uses keris as its main icon. It is also able to strengthen the Jateng Gayeng brand identity because it has been proven by the recognition of the keris as a world heritage by UNESCO [7]. Keris is not only considered a work of art and visual object, but it is also used to show the wearer's social status [8]. It is believed to have special spiritual power and people who have it are thought to be able to get more charisma. This is a masterpiece in the field of metal forging that has been inherent and present in the midst of Javanese society as a means of completeness of life which is considered important. The existence of the keris and the values that are in it help shape the way of thinking and behavior of Javanese people in finding character and cultural identity.

Keris as an embodiment of Javanese cultural identity which is currently widely known and worldwide has become the main icon in the brand identity of Central Java. This prompted researchers to conduct research on how the relationship between keris in Javanese culture and brand identity emerged. From this phenomenon can be examined the originality of the meaning of the keris which was elaborated as an embodiment of the characteristics of the Javanese community displayed on the brand identity of Jateng Gayeng. The performance of the keris representation as an icon in the Jateng Gayeng brand identity can be assessed through this research, how the value in the keris brought to represent Central Java is on the international scene. As the objectives of the Central Java Provincial Government want to achieve, the keris is expected to be a mainstay of determining its success. This research is expected to produce new findings for the development of further research, especially in the fields of art, design, and culture.

\section{METHOD}

The method in this study is qualitative and descriptive. This study uses the theory of art criticism from Feldman (1967), which there are four types of art criticism, namely popular criticism, journalist criticism, scientific criticism, and educational criticism. Scientific art criticism was chosen to analyze this research because it is a type of criticism that is academic with an insight into knowledge, ability, and sensitivity to assess or respond to a work of art. This type of criticism is generally conveyed by following the criteria or methodology of criticism academically. The results of responses through scientific criticism are often used as a reference for future research. There are four stages of scientific art criticism, that is description, formal analysis, interpretation, and evaluation. Descriptions are stages to pay attention to, find various elements, and explain what looks like. Formal analysis is the stage of search based on existing structures. Interpretation is the interpretation of meaning, the symbol presented and the sign that is raised. Evaluation is the last step to determine the quality of the keris representation in the Jateng Gayeng brand identity. Data collection techniques are carried out through literature, archives, and documents. The place of research was conducted in Central Java as a province that has a brand identity Jateng Gayeng. 


\section{RESULT AND DISCUSSION}

\subsection{Structure of the Jateng Gayeng Brand Identity}

Jateng Gayeng is the brand identity of Central Java Province. The design is done by the contest method which is then chosen and determined by the "Branding Team". The word "jateng" is used to refer to the shortened Central Java. This is necessary because the word "jateng" is easier and shorter to say. The word is also easier to remember, considering that the word "jateng" has been commonly used and spoken in the daily lives of people in Indonesia. The form of the brand identity examined is the logo. The medium used is a vector image made by processing computer software. The results of these vector images can be applied in various print and digital media, depending on the needs of the work. The size can be adjusted to the fields used, ranging from small fields to large fields. This logo is a logotype that reads "jateng gayeng" using a modified lowercase letter, for example, sees Figure 1. The axis of this logo is horizontal with the position of the word "jateng" at the top looking more dominating and larger than the word "gayeng". The lines that make up the fields into letters in the logo form a regular thickness letter structure in the script font family. Each letter is not interconnected, but each end is dominated by a sharp shape. The maroon color is used as a single color in all parts of this logo.

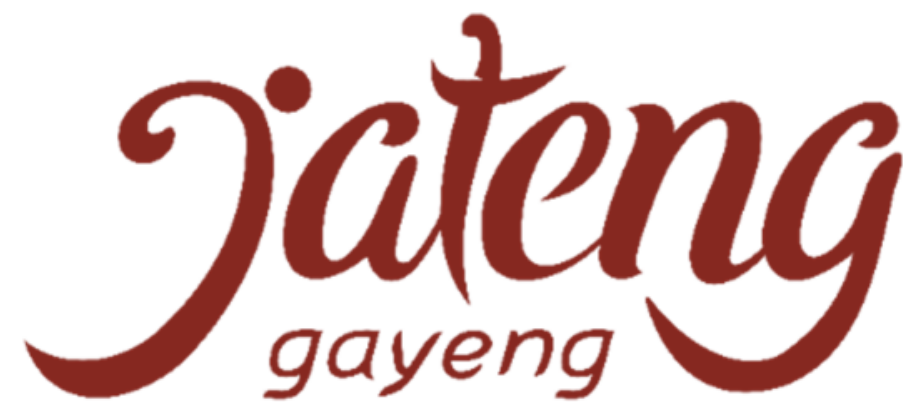

Figure. 1. Logo of Jateng Gayeng Brand Identity

In the center of the logo, there is a keris symbol used to replace the letter " $t$ " in the word "jateng". The keris symbol is applied as an icon in the logo, as well as the letter " $t$ ". Its position in the middle and sticking up makes the visibility easy to see. The keris icon becomes a point of view on the logo, even though it uses the same maroon color. It is described in full with the warangka, it is a keris holster [5], made from various kind of materials, but most of them are made from wood to hold the blade which can be coated with metals, such as brass, iron, silver, or gold. The keris icon faces down with a pointed tip structure. The depiction tries to be visualized into a silhouette of a keris that is identical to the original. The silhouette is modified and adjusted to the overall composition of the logo until it reaches balanced proportions.

\subsection{Keris Icon in the Jateng Gayeng Brand Identity}

Keris icon in Jateng Gayeng brand identity is displayed as a visual element in the position in the middle of the logo. It is now interpreted as a symbolic visual element, so the curved shape of the keris becomes an aesthetic element of the logo or symbol in it [7]. Aside from being an aesthetic element, the keris is also used as a substitute for the letter " $\mathrm{t}$ " in the word "jateng". That is because the keris icon is identical to the letter " $\mathrm{t}$ " if positioned facing down, for more details can be seen in Figure 2. 

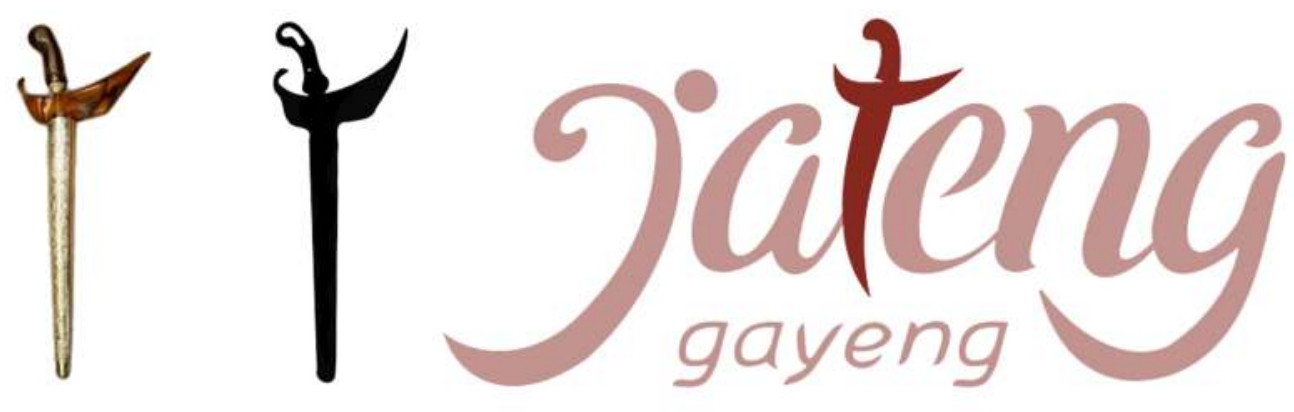

Fig. 2. Keris, Silhouette of Keris, and Keris Icon in Jateng Gayeng Brand Identity

Keris, which originally functioned as weapons, now encountered a shift in function and meaning. People believe that the keris is "tosan aji" not a weapon [5]. This raises that the keris is believed to be able to foster confidence in the owner. It became an expensive item and a collection of a handful of people who believed in its spiritual power, thus giving rise to its own peculiarities. Another thing that appears from this phenomenon is the keris raises prestige elements [7]. The owner of the keris can believe how he feels he has the special power contained in it.

In articulating the visual elements of the line will find the concept of symbols, each of which corresponds to the typology of signs [6]. The keris icon in the form of a symbol that is presented in the brand identity of Jateng Gayeng can be found a sign articulated into meaning. Visually, it does not display one type of keris specifically, based on the various types of keris that exist. The icon summarizes various types of keris into visual unity. This is so that the general public can easily accept that the icon presented is a symbol of the keris, which he has a series of meanings to convey through the Jateng Gayeng brand identity.

\subsection{The Value of Keris as Main Icon in The Jateng Gayeng Brand Identity}

The meaning of the philosophy of the keris is in its motif or prestige. It consists of mixing the owner's expectations, the creations of the keris maker and the strength that is in the quality of metals, which the process requires precision and tested choices. Keris is expected to be able to give honor to the wearer. It has a symbolic meaning that is full of unique shapes and styles, that's where it has characteristics [7]. Keris in a perpendicular shape, if an imaginary line is drawn, it will form a triangle. There are triangles that are symmetrical but are mostly asymmetrical. Triangles that are formed imaginably in a keris which are perpendicular are depictions of mountains or trees that manifest themselves in ancestral spirits. The tip of the sharp blade of the keris symbolizes the sharpness of the human mind and heart so that humans can be sensitive creatures in reading natural signs. The front face of the keris is a symbol that's the personification of the human body as an image [6]. In terms of culture, keris is a part of the art. Keris as a result of Javanese culture which lasted for such a long time, its role and function have penetrated the lives of Javanese people. Through the keris, it can be understood to what extent the level of culture, technology, social strata, politics, art, spiritual and religious understanding and other social joints [9].

Seeing a brand or symbol is very interesting to study, in this case, related to local identity idioms that function symbolically appear in brand identity or symbol as the identity of a region. 
Brand identity is the core of a brand, a unique characteristic compared to other brands is the visual appearance and perception inherent in society [10]. In the Jateng Gayeng brand identity, perceptions that are inherent in the minds of the people begin to appear, making a characteristic unique compared to other regions based on local culture so that it can also be highlighted as a reinforcing element of brand identity. Logo, symbol, brand contains symbolic elements in it. People will understand symbolic texts that are made so interesting and meaningful. Symbols or logos included in them have aesthetic value. Traditional Javanese keris or weapons have become one of the UNESCO world heritage nominated on November 25, 2005. This can strengthen the brand identity of Central Java which embeds the keris symbol in the Jateng Gayeng logo. Seeing the existence of a keris symbol on a commercial logo brand or other agency now may have existed in a few years ago. The iconic symbol of the keris of the type of straight keris and the type of winding keris, are used in government and institutional symbols in several provinces and districts in Indonesia. This means that the keris has a position of philosophical meaning that is strong enough for the East spiritual belief community, especially in Central Java. Symbols or logos in the world of visual communication and advertising are a form of marker or identity in other commercial institutions or businesses which are often referred to as brands or brand symbols. The process of building a successful brand does not stop at choosing brand names and images. Images are more memorable than words, this has been proven in psychology and marketing research [11]. Thus, the representation of the meaning of the keris that is depicted in the Jateng Gayeng logo can be examined in how to bring up the personality image of Central Java that is easy to remember and represents its cultural characteristics.

As Thurlow said in his research [12], symbolizing a keris can also be a powerful visual means of meaning in dominant identity processing. The Jateng Gayeng logo with the symbolization of an asymmetrical dagger shows that the shape can increase the intention of the brand to be higher, as evidenced by Luffarelli [13]. The association of the Jateng Gayeng brand identity is also influenced by government institutions, the community, and stakeholders as Muzellec stated in his research [14]. The functional and emotional values formed by the existence of the keris greatly enable the provincial government to introduce the promised brand experience to the general public [15]. The design of the identity brand Jateng Gayeng was not separated from the political process in the government bureaucracy, this was once conveyed by Kavaratzis [16]. The meaning contained in the brand identity of Central Java Gayeng is also inseparable from the intrinsic part of the behavior of people in Central Java, this is reinforced in the study of Martin [17]. In essence, Central Java raised the keris as its cultural identity visualized in the Jateng Gayeng brand identity is one of the efforts of identity politics. Keris is also often used as a compliment in traditional Javanese events, so, without the presence of a keris, it will be considered incomplete, including the Jateng Gayeng brand identity which is incomplete if there is no keris as its main icon. It also represents the positioning of someone in the community, by having it, someone will be considered to be of a higher degree to the social culture class, this is taken by the Jateng Gayeng brand identity as meaning that the keris icon is able to bring Central Java to a position that is valued in the eyes of the world. Keris in Java is also interpreted as a person, so it can represent someone's presence on certain occasions. Of course, the meaning of the keris is highly upheld, hence the keris icon on the brand identity of Jateng Gayeng can also represent the presence of Central Java wherever the brand identity is installed. 


\section{CONCLUSION}

If the keris is seen as a symbol in the Jateng Gayeng logo, it is described as a whole with a harmonious unity, this means that Central Java as a province with its full potential remains a unit that continues to encourage the implementation of goals in the process of enhancing the image of the region. Coupled with the word "gayeng" which is at the bottom of the logo, this has the meaning of giving or fun, so with so many essential meanings from the keris, it is also expected to be able to bring Central Java as an exciting and pleasant area for all parties. Asymmetrical forms of keris as a visual means that have an impact on intention to brand identity add to the wealth of meaning, namely the sharpness of human thought and heart so that humans can become sensitive creatures in reading natural signs. Other meanings have a picture of human life which is always in the process of achieving. There is no perfect human, nothing is fulfilled. Human life must always be dynamic and have the will to go forward. Moreover, the people of Central Java are people who worship beauty, and this is reflected in the keris as a symbol of the Jateng Gayeng logo. Trust from the wider community and the international community also supports the process of developing images in Central Java through the brand identity of Jateng Gayeng in order to strengthen the image that is easy to remember, easily known and increasingly popular.

\section{REFERENCES}

[1] R. K. Srivastava, "Understanding brand identity confusion," Mark. Intell. Plan., 2011.

[2] C. da Silveira, C. Lages, and C. Simões, "Reconceptualizing brand identity in a dynamic environment," J. Bus. Res., 2013.

[3] M. Urde, "The corporate brand identity matrix," in Journal of Brand Management, 2013.

[4] M. Margunani, I. Hidayah, and I. Melati, "Firing up Excellent Entrepreneur Embryos in Semarang State University, Indonesia," 2017.

[5] H. Budi and R. Peterzon, "Hybrid Method and Similarity to Recognize Javanese Keris," Int. J. Adv. Comput. Sci. Appl., 2015.

[6] W. Ariwibowo, A. Purwasito, and T. S. Pitana, "SHAPES OF JAVANESE KERIS AS A SYMBOLIC SIGN: TRANSFORMATION TOWARD THE ISLAMIC PERIOD,” EL HARAKAH, 2017.

[7] M. Handriyotopo and L. L. Simatupang, "Keris Symbols in The Emblem and Brand Logo," 2018.

[8] D. W. H. Rassers, "On the Javanese Kris," Bijdr. tot taal-, land- en Volkenkd. / J. Humanit. Soc. Sci. Southeast Asia, 2013.

[9] A. Purnawangsih, S. Subiyantoro, and E. T. Sulistyo, "the Analysis of Keris From Authority and World Cultural Behavior," pp. 523-530.

[10] N. Zhang et al., "Brand identity development and the role of marketing communications: brand experts' view," PLoS One, 2013.

[11] P. T. Adidam, "Brand Identities: A Framework for Successful Branding," Paradigm, 2015.

[12] C. Thurlow and G. Aiello, "National pride, global capital: A social semiotic analysis of transnational visual branding in the airline industry," Vis. Commun., 2007.

[13] J. Luffarelli, A. Stamatogiannakis, and H. Yang, "The Visual Asymmetry Effect: An Interplay of Logo Design and Brand Personality on Brand Equity," J. Mark. Res., 2018.

[14] L. Muzellec and M. C. Lambkin, "Corporate branding and brand architecture: A conceptual framework," Mark. Theory, 2009.

[15] N. Petek, "Brand Experts 'View," vol. 11, no. 1, pp. 61-78, 2007. 
[16] M. Kavaratzis and A. Kalandides, "Rethinking the place brand: the interactive formation of place brands and the role of participatory place branding," Environ. Plan. A, 2015.

[17] I. M. Martin, D. W. Stewart, and S. Matta, "Branding strategies, marketing communication, and perceived brand meaning: The transfer of purposive, goal-oriented brand meaning to brand extensions," J. Acad. Mark. Sci., 2005. 